\title{
UNDERSTANDING OF SYSTEMS OPERATION
}

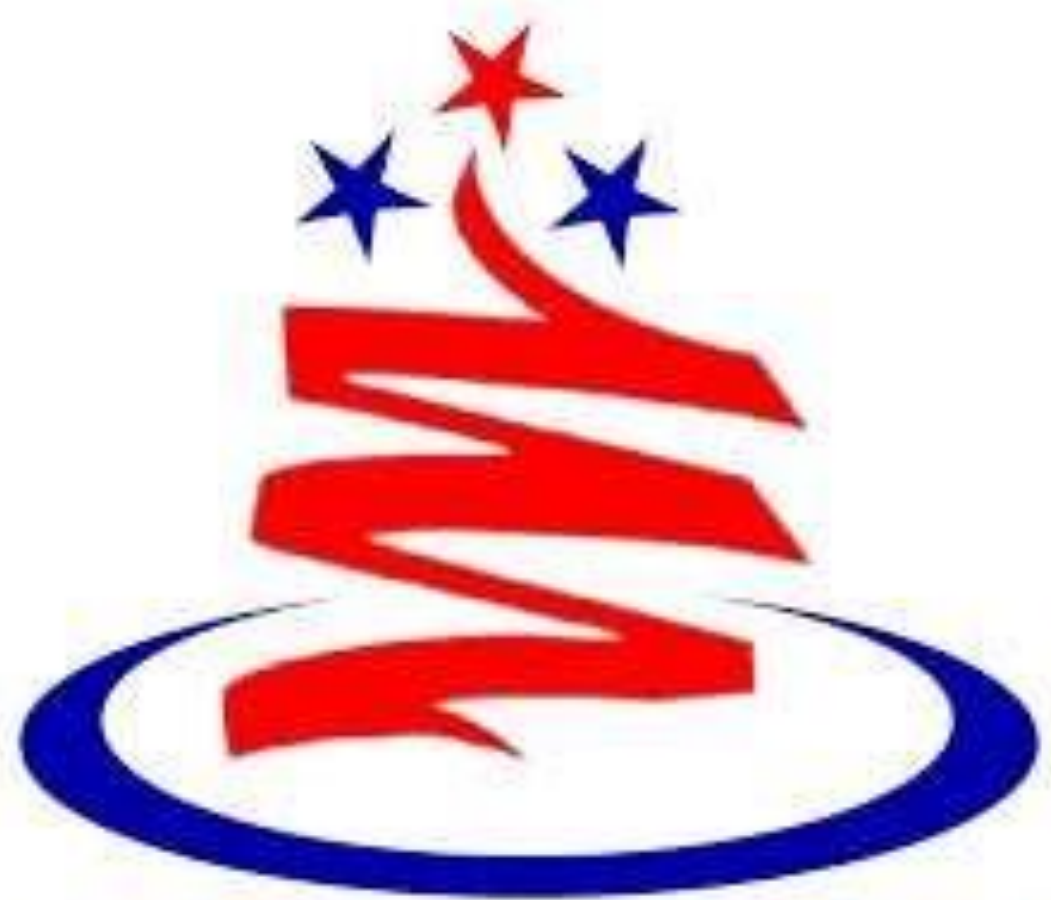

\section{UNIVERSITAS MITRA InDONESIA}

\author{
Novialindra Chika Salsabila \\ 195120005
}

Fakultas Komputer

novialindra.student@umitra.ac.id 


\section{Abstract}

Dalam istilah ilmu komputer, sebuah sistem operasi adalah adalah perangkat lunak sistem yang mengatur sumber daya dari perangkat keras(Hardware) dan perangkat lunak(Software), serta sebagai jurik (daemon) untuk program komputer.

Tanpa sistem operasi, pengguna tidak dapat menjalankan program aplikasi pada komputer mereka, kecuali program booting. Sistem operasi mempunyai penjadwalan yang sistematis mencakup perhitungan penggunaan memori, pemrosesan data, penyimpanan data, dan sumber daya lainnya.

Contoh Sistem Operasi modern adalah : Linux, Android, iOS , Mac OS X, dan Microsoft Windows. 


\section{A. PENDAHULUAN}

Materi Kuliah Semester 3 Membahas Tentang Sistem Operasi.

\section{Latar Belakang}

Dalam rangka memenuhi tugas mata kuliah Sistem Operasi maka di buatlah makalah dengan judul "UNDERSTANDING OF SYSTEMS OPERATION" yang akan di upload di OSF dan dapat memperbanyak refrensi tetang Sistem Operasi.

\section{B. PEMBAHASAN / STUDI KASUS}

\section{PENGERTIAN SISTEM OPERASI :}

Dalam istilah ilmu komputer, sebuah Sistem Operasi adalah perangkat lunak sistem yang mengatur sumber daya dari perangkat keras (Hardware) dan perangkat lunak (Software), serta sebagai jurik (Daemon) untuk program komputer.

Sistem Operasi merupakan program yang mengatur eksekusi program dan bertindak sebagai interface antara aplikasi dan perangkat keras.

Tujuan Sistem Operasi adalah memberikan kemudahan, Efisiensi terhadap pengguna serta memiliki kemampuan untuk berkembang.. 
- Komponen Sistem Operasi

Komponen Sistem Operasi adalah Managemen Proses, Managemen Memori Utama, Managemen Berkas, Managemen I/O, Managemen Penyimpanan Sekunder, Jaringan, Sistem Proteksi dan Command-Interpreter System.

Jenis-Jenis Sistem Operasi : DOS (Disk Operating Sistem), WINDOWS, MACINTOSH, OS/2 (Operating sistem/2) dan LINUX.

\section{- Layanan yang ada dalam system Operasi}

Sistem Operasi memiliki beberapa layanan, yaitu menyediakan user interface, program execution, I/O operations, file-system manipulation, system communications / networking, mampu melakukan error detection.

mampu melakukan resource Sharing, ada fasilitas security dan adanya fasilitas accounting system.

- Perbedaan antara Process dan Thread yang ada dalam system operasi

Process : suatu aplikasi yang sedang berjalan

Thread: beberapa pekerjaan yang dijalankan dalam 1 prosesnya dalam1 prosesnya.

Adanya prosess dan thread memungkinkan untuk membagi pekerjaan menjadi terstruktur

\section{- Process Schedulling}

Process Schedulling adalah Aktifitas yang digunakan untuk menjadwalkan program mana yang akan dieksekusi 


\section{- Synchronization}

Synchronization adalah Akses secara konkuren (hampir bersamaan) terhadap data yang bersifat shared yang dapat menyebabkan data tidak konsisten atau rusak/korup.

Jika terjadi race condition, maka diperlukan mekanisme sinkronisasi untuk menghindari kejadian seperti di atas

\section{Beberapa algoritma sinkronisasi}

- FCFS (First Come First Served)

- SJF (Shortest Job First)

- RR (Round Robin)

\section{Virtual Memory}

Virtual Memori adalah memori yang diciptakan untuk menambah memory utama yang terbatas, sehingga hanya bagian dari program yang dibutuhkan saja yang harus ada dalam memory untuk dieksekusi, memory juga dapat dimodifikasi sesuai kebutuhan.

\section{Perangkat I/O}

- Perangkat block meliputi berbagai disk drive, perintah baca, tulis, pencarian data serta dapat digunakan untuk mengakses memory pada disk.

- Perangkat characterc ontohnya adalah eyboard, mouse yang digunakan untuk menulis, mengambil serta dapat dibuat library pengakses data per-baris

- Perangkat jaringan memiliki Socket, yaitu penghubung komputer dengan jaringan. 


\section{Sistem Operasi Linux}

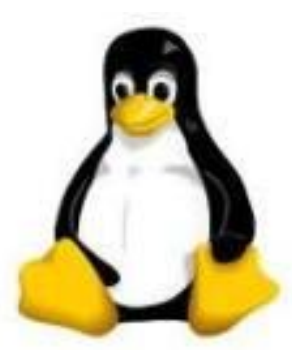

Awalnya dibuat oleh mahasiswa Finladia yang bernama : Linus Tovalds.

Saat ini Sistem Operasi linux banyak digunakan untuk berbagai kepentingan, diantaranya: server web, file server, desktop, dll

- LINUX bisa diperoleh dalam berbagai distribusi (sering disebut DISTRO)

- DISTRO adalah bundel dari kernel LINUX, besertasystemdasar LINUX,

Program instalasi, tools basic dan program-program lain yang bermanfaat sesuai dengan tujuan pembuatan DISTRO.

\section{Struktur Directory Linux}

File sistem linux berbeda dengan Windows, linux menggunakan sistem direktori-direktori untuk menyimpan file-file nya

Misalnya bin berisi file-file binary standar yang dapat digunakan oleh seluruh user baik user biasa maupun super user, boot berisi file-file yang digunakan untuk booting Linux termasuk kernel image dan /dev berisi file system khusus yang merupakan refleksi device hard-ware yang dikenali dan digunakan system.

Perintah-perintah ini dikerjakan dengan memasukkan kata kunci untuk suatu task tertentu, namun, pada versi desktop, telah menggunakan GUI untuk melakukan pekerjaan struktur Perintah di Linux. 
Contoh : [root@localhost root]\# nama_perintah [pilihan] [argumen]

Keterangan :

[root@localhost root]èprompt Linux yang berarti anda login sebagai root yang berada pada host(mesin) localhost dan berada dalam directory root, tanda\# menunjukkan sebagai super user.

-Nama_perintah $=$ Perintah standar yang dijalankan shell.

-Pilihan = Untuk memberi opsi (mengubah atau menambah) dari keadaan default.

-argument = objek yang akan diproses oleh perintah (dapat dikosongkan).

\section{Install Software dengan TAR dan RPM}

Linux mengenal dua metode instalasi yaitu binary dan kode sumber, yaitu

RPM (Red Hat Package Manager) dan TAR yang memiliki format install yang lebih umum. Perintah di Linux itu case sensitive, dan tidak semudah install di OS milik Microsof

\section{Install Software dengan RPM}

- Untuk menginstall cukup dengan format perintah : [root]\# rpm -I p []p

- Jika ingin mengupgrade aplikasi : [root]\# U 


\section{Manajemen User OS Linux}

Standar Sistem Operasi adalah mampu mengatur user atau pemakai OS, ex : menamba h pengguna (sebagai host atau bukan) dan memberikan keamanan (password)

Perintah dasarnya adalah : Useradd nama_pengguna dan passwd password_pengguna Standar Sistem Operasi adalah mampu mengatur user atau pemakai OS, ex : menamba h pengguna (sebagai host atau bukan) dan memberikan keamanan (password)

Perintah dasarnya adalah : Useradd nama_pengguna dan passwd password_pengguna 


\section{B. ID SECURITY}

QWTD44112377-ASP-524414475

\section{REFERENCE}

[1] O. M. Febriani and A. S. Putra, "Sistem Informasi Monitoring Inventori Barang Pada Balai Riset Standardisasi Industri Bandar Lampung," J. Inform., vol. 13, no. 1, pp. 90-98, 2014.

[2] A. S. Putra, "Paperplain: Execution Fundamental Create Application With Borland Delphi 7.0 University Of Mitra Indonesia,” 2018.

[3] A. S. Putra, “2018 Artikel Struktur Data, Audit Dan Jaringan Komputer,” 2018.

[4] A. S. Putra, "ALIAS MANAGER USED IN DATABASE DESKTOP STUDI CASE DB DEMOS."

[5] A. S. Putra, "COMPREHENSIVE SET OF PROFESSIONAL FOR DISTRIBUTE COMPUTING."

[6] A. S. Putra, "DATA ORIENTED RECOGNITION IN BORLAND DELPHI 7.0."

[7] A. S. Putra, "EMBARCADERO DELPHI XE 2 IN GPU-POWERED FIREMONKEY APPLICATION."

[8] A. S. Putra, "HAK ATAS KEKAYAAN INTELEKTUAL DALAM DUNIA TEKNOLOGY BERBASIS REVOLUSI INDUSTRI 4.0.”

[9] A. S. Putra, "IMPLEMENTASI PERATURAN PERUNDANGAN UU. NO 31 TAHUN 2000 TENTANG DESAIN INDUSTRI BERBASIS INFORMATION TECHNOLOGY."

[10] A. S. Putra, "IMPLEMENTATION OF PARADOX DBASE."

[11] A. S. Putra, "IMPLEMENTATION OF TRADE SECRET CASE STUDY SAMSUNG MOBILE PHONE."

[12] A. S. Putra, "IMPLEMENTATION PATENT FOR APPLICATION WEB BASED CASE STUDI WWW. PUBLIKLAMPUNG. COM."

[13] A. S. Putra, "IMPLEMENTATION SYSTEM FIRST TO INVENT IN DIGITALLY INDUSTRY."

[14] A. S. Putra, "MANUAL REPORT \& INTEGRATED DEVELOPMENT ENVIRONMENT BORLAND DELPHI 7.0.” 
[15] A. S. Putra, "PATENT AS RELEVAN SUPPORT RESEARCH."

[16] A. S. Putra, "PATENT FOR RESEARCH STUDY CASE OF APPLE. Inc."

[17] A. S. Putra, "PATENT PROTECTION FOR APPLICATION INVENT."

[18] A. S. Putra, "QUICK REPORT IN PROPERTY PROGRAMMING.”

[19] A. S. Putra, "REVIEW CIRCUIT LAYOUT COMPONENT REQUIREMENT ON ASUS NOTEBOOK."

[20] A. S. Putra, "REVIEW TRADEMARK PATENT FOR INDUSTRIAL TECHNOLOGY BASED 4.0."

[21] A. S. Putra, "TOOLBAR COMPONENT PALLETTE IN OBJECT ORIENTED PROGRAMMING."

[22] A. S. Putra, "WORKING DIRECTORY SET FOR PARADOX 7."

[23] A. S. Putra, "ZQUERY CONNECTION IMPLEMENTED PROGRAMMING STUDI CASE PT. BANK BCA Tbk."

[24] A. S. Putra, D. R. Aryanti, and I. Hartati, "Metode SAW (Simple Additive Weighting) sebagai Sistem Pendukung Keputusan Guru Berprestasi (Studi Kasus: SMK Global Surya)," in Prosiding Seminar Nasional Darmajaya, 2018, vol. 1, no. 1, pp. 85-97.A. S. Putra and O. M. Febriani, "Knowledge Management Online Application in PDAM Lampung Province," in Prosiding International conference on Information Technology and Business (ICITB), 2018, pp. 181-187.

[25] A. S. Putra, O. M. Febriani, and B. Bachry, "Implementasi Genetic Fuzzy System Untuk Mengidentifikasi Hasil Curian Kendaraan Bermotor Di Polda Lampung," SIMADA (Jurnal Sist. Inf. dan Manaj. Basis Data), vol. 1, no. 1, pp. 21-30, 2018.

[26] A. S. Putra, H. Sukri, and K. Zuhri, "Sistem Monitoring Realtime Jaringan Irigasi Desa (JIDES) Dengan Konsep Jaringan Sensor Nirkabel," IJEIS (Indonesian J. Electron. Instrum. Syst., vol. 8, no. 2, pp. 221-232.

[27] D. P. Sari, O. M. Febriani, and A. S. Putra, "Perancangan Sistem Informasi SDM Berprestasi pada SD Global Surya," in Prosiding Seminar Nasional Darmajaya, 2018, vol. 1, no. 1, pp. 289-294. 